\title{
The Japanese Experience with Basic Fibroblast Growth Factor in Cutaneous Wound Management and Scar Prevention: A Systematic Review of Clinical and Biological Aspects
}

\author{
Mohamed Abdelhakim (D) - Xunxun Lin · Rei Ogawa
}

Received: May 5, 2020 / Published online: June 6, 2020

(C) The Author(s) 2020

\begin{abstract}
Introduction: Basic fibroblast growth factor (bFGF) plays several key roles in wound healing. Over the last 2 decades, clinical and basic research on bFGF has been actively conducted in Japan with reports on its potent efficacy in accelerating the healing of chronic ulcers and burn wounds by stimulating key cellular players in the skin. However, its efficacy remains unrecognized internationally. Thus, this study reviews current knowledge about the therapeutic value of bFGF in wound management and scar prevention accumulated in Japan over the last 2 decades.

Methods: We review the Japanese literature that demonstrates the anti-scarring effects of bFGF and exhaustively assess how these effects
\end{abstract}

Digital Features To view digital features for this article go to https://doi.org/10.6084/m9.figshare.12387983.

M. Abdelhakim $(\bowtie) \cdot$ R. Ogawa

Department of Plastic, Reconstructive and Aesthetic

Surgery, Nippon Medical School, 1-1-5 Sendagi,

Bunkyo-ku, Tokyo 113-8603, Japan

e-mail: mohamed-abdelhakim@nms.ac.jp

X. Lin

Department of Plastic Surgery, The First Affiliated

Hospital of Sun Yat-sen University, Guangzhou

510080, China are exerted. Using the search terms "bFGF OR growth factors AND wound healing in Japan" and "bFGF AND scar prevention in Japan," we conducted a search of the PubMed database for publications on the role of bFGF in wound and scar management in Japan. All eligible papers published between 1988 and December 2019 were retrieved and reviewed.

Results: Our search yielded 208 articles; 82 were related to the application of bFGF for dermal wound healing in Japan. Of these, 27 fulfilled all inclusion criteria; 11 were laboratory studies, 7 were case reports, 4 were clinical studies, and 5 were randomized controlled trials.

Conclusion: Further research, with recognition of the therapeutic value of bFGF in wound and scar management and its clinical applications, is needed to provide additional clinical advantages while improving wound healing and reducing the risk of post-surgical scar formation.

Keywords: Basic fibroblast growth factor; Burn injuries; Chronic ulcer; Wound healing; Scar prevention 


\section{Key Summary Points}

This article reviews current knowledge about the therapeutic efficacy of bFGF in wound management and scar prevention, which has been accumulated in Japan over the last 2 decades, including Japanese animal model studies, case reports, clinical studies, and randomized controlled trials.

The application of bFGF immediately after debridement and before grafting can improve the healing of chronic ulcers or second-degree burns and prevent pathological scar development.

bFGF signaling promotes both fibroblast proliferation and migration in wound healing by activating the PI3K/Rac1/JNK pathway and may prevent pathological scar formation by inhibiting TGF $\beta 1 / \mathrm{SMAD}$ signaling.

Several bFGF delivery systems are being developed, including controlled-release bFGF formulations such as bFGF gelatin sheets, which provide better healing outcomes. However, further research on these alternative formulations may provide optimal clinical advantages.

\section{INTRODUCTION}

Wound healing normally is a finely orchestrated multi-phase process that involves a variety of cell types. Studies on wound healing have revealed that dysfunction in some growth factors plays a role in non-healing wounds. These findings have directed advanced bioengineering technology to consider the use of exogenously prepared growth factors and cytokines.

Several growth factors have demonstrated potent efficacy for surgical use such as plateletderived growth factor (PDGF) [1], vascular endothelial growth factor (VEGF) [2], fibroblast growth factor (FGF), epidermal growth factor (EGF), keratinocyte growth factor (KGF), transforming growth factor beta (TGF- $\beta$ ), and granulocyte-macrophage colony-stimulating factor (GM-CSF) [3, 4].

Preparations that contain recombinant growth factors are available for external use in various formulations, for example, solution, spray, ointment, and gel. However, as summarized in Table 1, the use of these preparations is associated with certain limitations regarding safety and drug delivery systems, which require high doses and/or repeated application, resulting in dire side effects including oncogenesis [5-7].

In this article, we focus on basic fibroblast growth factor (bFGF), a member of the FGF family of growth factors and signaling proteins. In 1988, Kaken Pharmaceutical Co., Ltd., Tokyo, Japan, obtained exclusive licensing rights to recombinant human bFGF (rhbFGF) Trafermin. This drug was originally developed for patients with decubitus ulcers and skin ulcers.

Following several clinical trials and extensive research and development focusing on rhbFGF for tissue regeneration, in 2001, Kaken Pharmaceutical successfully launched Fiblast ${ }^{\circledR}$, the world's first rhbFGF preparation marketed in Japan as a topical spray for accelerating healing of burn wounds and diabetic leg ulcers. During the ensuing 8 years, it was observed that Fiblast $^{\circledR}$ spray potently and safely promoted wound healing and reduced scar formation in the clinical setting throughout Japan. Based on these findings, along with additional clinical research and good safety data, the Clinical Practice Guidelines for Burn Injuries published by the Japanese Society for Burn Injuries in 2009 recommended bFGF as treatment for seconddegree burns. Since then, bFGF has become widely used as a treatment modality for wound healing and scar reduction in the clinical setting in Japan.

However, the excellent efficacy of bFGF in wound healing remains largely unrecognized internationally. This may reflect the fact that while other countries have also conducted research on the ability of growth factors to improve wound healing, clinical and basic research in Japan has proactively investigated the role of bFGF in wound healing over the last 
Table 1 Specific growth factors and their roles in clinical applications for promoting wound healing

\begin{tabular}{|c|c|c|c|}
\hline $\begin{array}{l}\text { Growth } \\
\text { factors }\end{array}$ & $\begin{array}{l}\text { Platelet-derived } \\
\text { growth factor PDGF } \\
\left(\text { Regranex }{ }^{\circledR}\right)\end{array}$ & $\begin{array}{l}\text { Vascular endothelial growth factor } \\
\text { (VEGF 165) }\end{array}$ & $\begin{array}{l}\text { EGF Epidermal growth factor } \\
\left.\text { (Heberprot- } \mathbf{P}^{\circledR}\right)\end{array}$ \\
\hline Administration & Topical & Topical & $\begin{array}{l}\text { Topical or intralesional } \\
\text { Injection }\end{array}$ \\
\hline Type of wound & Diabetic foot ulcer & Diabetic foot ulcer & $\begin{array}{l}\text { Burns, non-healing ulcer, and diabetic } \\
\text { foot ulcer }\end{array}$ \\
\hline Action & $\begin{array}{l}\text { Maintains cell growth } \\
\text { and division, chemo- } \\
\text { attractant for } \\
\text { mesenchymal } \\
\text { cells, angiogenesis }\end{array}$ & $\begin{array}{l}\text { Enhances angiogenesis; stimulating } \\
\text { proliferation and migration of } \\
\text { endothelial cells }\end{array}$ & $\begin{array}{l}\text { Promotes proliferation and migration of } \\
\text { keratinocytes and tensile strength of } \\
\text { new skin; induces fibronectin } \\
\text { production }\end{array}$ \\
\hline \multirow[t]{2}{*}{ Limitations } & $\begin{array}{l}\text { Increased cancer risk } \\
\text { reported with higher } \\
\text { doses }\end{array}$ & $\begin{array}{l}\text { Few attempts of using VEGF as an } \\
\text { adjunctive treatment in wound } \\
\text { healing }\end{array}$ & $\begin{array}{l}\text { Healing is hindered by matrix } \\
\text { metalloproteinases rapidly degrading } \\
\text { growth factors or cytokines. }\end{array}$ \\
\hline & $\begin{array}{l}\text { Minimal efficacy in } \\
\text { pressure ulcers and } \\
\text { venous ulcers }\end{array}$ & $\begin{array}{l}\text { Most VEGF therapies are focused on } \\
\text { anticancer treatments by inhibiting } \\
\text { proliferation of tumor blood vessels }\end{array}$ & $\begin{array}{l}\text { Lack of sophisticated delivery systems } \\
\text { for providing sustained levels of EGF } \\
\text { and inhibiting its degradation. } \\
\text { Pain at the injection site is common }\end{array}$ \\
\hline Reference(s) & {$[73-75]$} & {$[76-79]$} & {$[80,81]$} \\
\hline
\end{tabular}

Recombinant growth factors are available in various formulations (e.g., solution, spray, ointment, and gel). However, some limitations regarding safety, cost, and drug delivery systems accompany these medications as listed above

20 years and are thus at the forefront of clinical experience and research leading this application.

In North America and Europe, significant attention has been paid and massive efforts have been focused on FGFs to generate FGFR inhibitors for application in the field of oncology $[8,9]$. In China, recent advances in bioengineering have led to the production of FGF ligands, revealing their role in enhancing wound repair and regeneration of injured tissue [10-13].

Simultaneously, the clinical application of FGF ligands in the field of oncology as well as in wound healing has been reported in Japan. Nevertheless, the Japanese clinical experience with FGF ligand products, especially bFGF, has demonstrated a remarkable positive impact in accelerating the process of healing and in the management of chronic wounds such as diabetic foot ulcers. Thus, improving the recognition of the potential clinical application of bFGF in wound healing and tissue repair in the West is necessary to overcome the financial burden of wound management, such as diabetic foot ulcers, and to provide sufficiently improved wound healing.

Therefore, in this article we review current knowledge about the therapeutic value of bFGF in wound management and scar prevention, which has been accumulated in Japan over the last 2 decades. In particular, we review animal studies, case reports, clinical studies, and randomized controlled trials (RCTs) that demonstrate the anti-scarring effects of bFGF in Japan. We also exhaustively assess the mechanism by which bFGF exerts these effects. 


\section{METHODS}

\section{Literature Search and Data Selection}

Using the search terms "bFGF OR growth factors AND wound healing in Japan" and "bFGF AND scar prevention in Japan," all original articles related to bFGF treatment in wound and scar management in Japan were identified by a PubMed search. Eligible papers published between 1988 and December 2019 were retrieved and reviewed. In addition, important reference articles from the included articles were reviewed. Three independent researchers performed the literature search to identify all relevant studies.

\section{Inclusion Criteria}

This study included articles that (1) reported on the use of topical bFGF in wound healing management and scar prevention; (2) described the effect of bFGF on these wounds. There were no restrictions with regard to the number of patients in the clinical study or the follow-up duration. The systematic review also aimed to include all in vivo studies that employed topical bFGF-treated models of wound healing and scarring along with all in vitro studies that involved bFGF-treated wounds or pathological scar-derived tissues/cells. The language of the article was not restricted to English.

\section{Exclusion Criteria}

The following articles were excluded: (1) articles on the use of bFGF for non-cutaneous wound healing; (2) imperfect literature reviews; (3) conference papers that reported data with unresponsive associated authors; (4) repeated publications.

\section{Statistical Analysis}

No formal statistical analysis was performed because the extensive methodological heterogeneity of the articles limited this study to a qualitative analysis. This article is based on previously conducted studies and does not contain any studies with human participants or animals performed by any of the authors.

\section{RESULTS}

A total of 208 articles were identified from the search, as shown in the Preferred Reporting Items for Systematic Reviews and Meta-Analyses (PRISMA) flowchart for literature attrition (Fig. 1). After screening by title, 82 were relevant to the application of bFGF for dermal wound healing in Japan. Subsequently, 60 were screened by abstract for adherence to the inclusion criteria.

Finally, a total of 27 full-text articles satisfied all the eligibility criteria and were reviewed in their entirety including: 11 laboratory studies, 7 case reports, 4 clinical studies, and 5 RCTs. The included articles are summarized (Tables 2, 3).

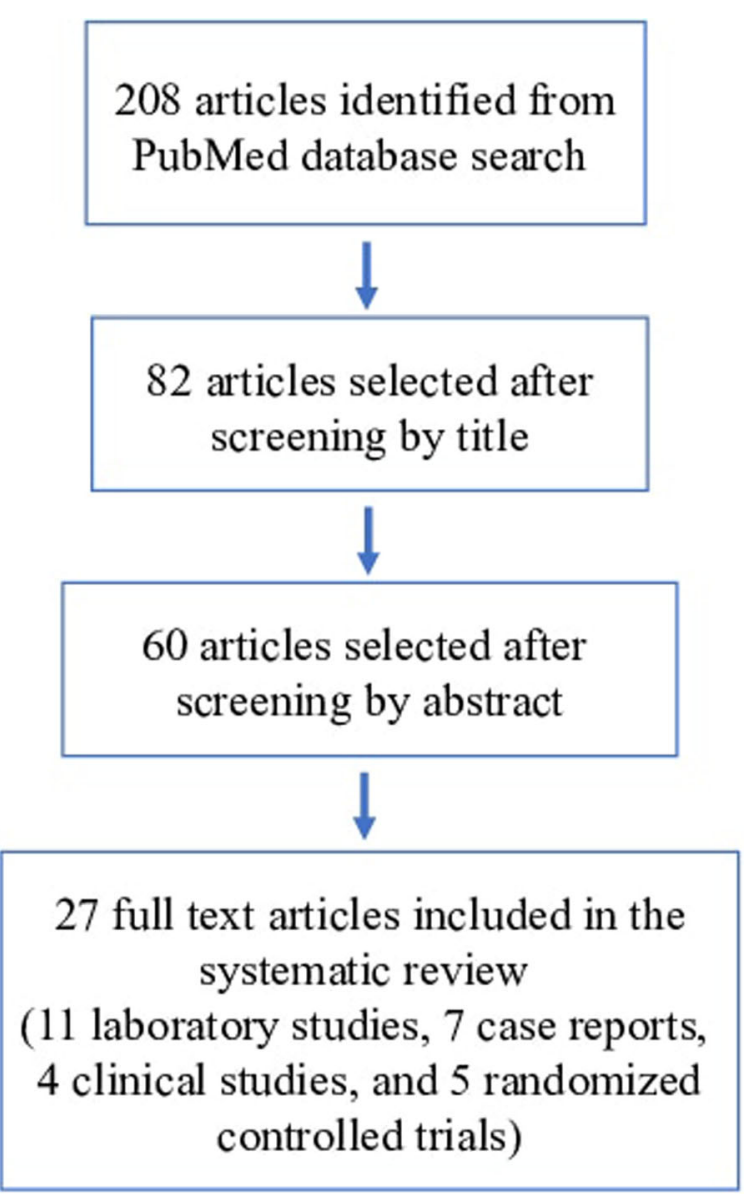

Fig. 1 PRISMA flowchart showing literature attrition 
Table 2 Laboratory studies on the role of bFGF in cutaneous wound management and scar prevention

\begin{tabular}{|c|c|c|c|c|}
\hline Title & $\begin{array}{l}\text { Type } \\
\text { of } \\
\text { study }\end{array}$ & Method & $\begin{array}{l}\text { Number } \\
\text { of } \\
\text { subjects }\end{array}$ & Results \\
\hline $\begin{array}{l}\text { Eto et al. } \\
\text { [33] }\end{array}$ & $\begin{array}{l}\text { In } \\
\text { vitro } \\
\text { In } \\
\text { vivo }\end{array}$ & $\begin{array}{l}\text { Evaluation of the therapeutic remodeling } \\
\text { effects of basic fibroblast growth factor } \\
\text { (bFGF) treatment in an animal model } \\
\text { using human hypertrophic scar tissue } \\
\text { implanted into nude mice }\end{array}$ & 6 & $\begin{array}{l}\text { Significant decrease in scar tissue weight } \\
\text { and collagen quantity }\end{array}$ \\
\hline $\begin{array}{l}\text { Funato et al. } \\
\qquad[34]\end{array}$ & $\begin{array}{l}\text { In } \\
\text { vitro }\end{array}$ & $\begin{array}{l}\text { Examination of the effect of bFGF on } \\
\text { apoptosis in normal rat palatal } \\
\text { fibroblasts and rat palatal scar fibroblasts } \\
\text { using the TUNEL assay }\end{array}$ & 3 & $\begin{array}{l}\text { bFGF induced apoptosis in myofibroblasts } \\
\text { during palatal scar formation }\end{array}$ \\
\hline $\begin{array}{l}\text { Akasaka } \\
\text { et al. [50] }\end{array}$ & $\begin{array}{l}\text { In } \\
\text { vitro }\end{array}$ & $\begin{array}{l}\text { Investigation of the mechanisms } \\
\text { underlying pro-apoptotic effects of } \\
\text { bFGF on granulation tissue fibroblasts } \\
\text { during wound healing after } \\
\text { pretreatment with transforming growth } \\
\text { factor (TGF)-betal }\end{array}$ & $5-7$ & $\begin{array}{l}\text { bFGF promoted apoptosis of injured } \\
\text { tissue-derived fibroblasts pre-treated } \\
\text { with TGF- } \beta 1\end{array}$ \\
\hline $\begin{array}{l}\text { Kanazawa } \\
\text { et al. [53] }\end{array}$ & $\begin{array}{l}\text { In } \\
\text { vitro }\end{array}$ & $\begin{array}{l}\text { Examination of bFGF-induced fibroblast } \\
\text { migration in wound healing with } \\
\text { concurrent blockade of the effect of } \\
\text { bFGF on fibroblast proliferation by } \\
\text { using mitomycin-C }\end{array}$ & 5 & $\begin{array}{l}\text { bFGF promoted dermal fibroblast } \\
\text { migration during the wound healing } \\
\text { process by activating the PI3K-Rac1- } \\
\text { JNK pathway }\end{array}$ \\
\hline $\begin{array}{l}\text { Kawai et al. } \\
\text { [65] }\end{array}$ & $\begin{array}{l}\text { In } \\
\text { vivo }\end{array}$ & $\begin{array}{l}\text { Evaluation of the effect of artificial dermis } \\
\text { with bFGF-impregnated gelatin } \\
\text { microspheres or bFGF in solution when } \\
\text { implanted into full-thickness skin } \\
\text { defects on the back of guinea pigs }\end{array}$ & 4 & $\begin{array}{l}\text { Incorporation of bFGF into the artificial } \\
\text { dermis demonstrated effectiveness by } \\
\text { accelerating fibroblast proliferation and } \\
\text { capillary formation in a dose-dependent } \\
\text { manner }\end{array}$ \\
\hline $\begin{array}{l}\text { Kanda et al. } \\
\text { [66] }\end{array}$ & $\begin{array}{l}\text { In } \\
\text { vitro } \\
\text { In } \\
\text { vivo }\end{array}$ & $\begin{array}{l}\text { Application of collagen-gelatin sponge } \\
\text { (CGS) impregnated with } 7 \mu \mathrm{g} / \mathrm{cm}^{2} \text { or } \\
14 \mu \mathrm{g} / \mathrm{cm}^{2} \text { of bFGF to full-thickness } \\
\text { skin defects of normal mice and } \\
\text { decubitus ulcers created in diabetic mice } \\
\text { (length of the neoepithelium, and total } \\
\text { area of newly formed capillaries in CGS } \\
\text { were evaluated) }\end{array}$ & 36 & $\begin{array}{l}\text { Artificial dermis, CGS, impregnated with } \\
7-\mu \mathrm{g} / \mathrm{cm}^{2} \text { bFGF accelerated dermis-like } \\
\text { tissue formation } 2 \text { or } 3 \text { times earlier } \\
\text { than artificial dermis alone }\end{array}$ \\
\hline
\end{tabular}


Table 2 continued

\begin{tabular}{|c|c|c|c|c|}
\hline Title & $\begin{array}{l}\text { Type } \\
\text { of } \\
\text { study }\end{array}$ & Method & $\begin{array}{l}\text { Number } \\
\text { of } \\
\text { subjects }\end{array}$ & Results \\
\hline $\begin{array}{l}\text { Kanda et al. } \\
\text { [67] }\end{array}$ & $\begin{array}{l}\text { In } \\
\text { vitro }\end{array}$ & $\begin{array}{l}\text { Evaluation of the ability of a scaffold, } \\
\text { CGS, for sustained release of bFGF, } \\
\text { using a pressure-induced decubitus ulcer } \\
\text { model in genetically diabetic mice by } \\
\text { assessment of the wound area and } \\
\text { histological assessment of neo- } \\
\text { epithelization }\end{array}$ & 40 & $\begin{array}{l}\text { CGSs impregnated with } 7-14 \mu \mathrm{g} / \mathrm{cm}^{2} \\
\text { bFGF accelerated wound healing }\end{array}$ \\
\hline $\begin{array}{l}\text { Tabata, } \\
\text { et al. [68] }\end{array}$ & $\begin{array}{l}\text { In } \\
\text { vitro } \\
\text { In } \\
\text { vivo }\end{array}$ & $\begin{array}{l}\text { Evaluation of the biological activity of } \\
\text { controlled release of bFGF incorporated } \\
\text { into gelatin hydrogel after subcutaneous } \\
\text { implantation into the back of mice }\end{array}$ & 6 & $\begin{array}{l}\text { Controlled release of biologically active } \\
\text { bFGF caused by biodegradation of the } \\
\text { acidic gelatin hydrogel induced a } \\
\text { prolonged vascularization effect }\end{array}$ \\
\hline $\begin{array}{l}\text { Tabata et al. } \\
{[69]}\end{array}$ & $\begin{array}{l}\text { In } \\
\text { vivo }\end{array}$ & $\begin{array}{l}\text { In vivo release of bFGF from a } \\
\text { biodegradable gelatin hydrogel carrier } \\
\text { was compared with in vivo degradation } \\
\text { of hydrogel in a diffusion chamber, and } \\
\text { implanted in the mouse subcutis for } \\
\text { certain periods of time }\end{array}$ & 6 & $\begin{array}{l}\text { Biologically-active bFGF was released as a } \\
\text { result of in vivo degradation of the } \\
\text { hydrogel and induced significant } \\
\text { neovascularization }\end{array}$ \\
\hline $\begin{array}{l}\text { Mizuno } \\
\text { et al. [70] }\end{array}$ & $\begin{array}{l}\text { In } \\
\text { vitro } \\
\text { In } \\
\text { vivo }\end{array}$ & $\begin{array}{l}\text { Examination of the stability of bFGF in a } \\
\text { chitosan film and the therapeutic effect } \\
\text { on wound healing in genetically diabetic } \\
\text { mice }(\mathrm{db} / \mathrm{db} \text { mice })\end{array}$ & 5 & $\begin{array}{l}\text { The rate of healing was accelerated by } \\
\text { promotion of fibroblast proliferation } \\
\text { and granulation tissue formation }\end{array}$ \\
\hline $\begin{array}{l}\text { Matsumoto } \\
\text { et al. [72] }\end{array}$ & $\begin{array}{l}\text { Ex } \\
\text { vivo }\end{array}$ & $\begin{array}{l}\text { Histological analyses of effectiveness of } \\
\text { bFGF-impregnated gelatin sheet in a } \\
\text { murine model }\end{array}$ & 4 & $\begin{array}{l}\text { The findings suggested that controlled } \\
\text { release of bFGF using gelatin sheet is } \\
\text { effective for promoting wound healing }\end{array}$ \\
\hline
\end{tabular}

\section{DISCUSSION}

\section{Clinical and Experimental Significance of bFGF}

\section{Local bFGF Treatment Accelerates Wound Healing}

Wound healing normally begins with hemostasis and then progresses through three overlapping phases driven by biomechanical responses, namely, inflammation, proliferation, and maturation. bFGF, along with other growth factors, plays key roles in wound healing as shown by the significantly slower healing of full-thickness skin wounds in bFGF-knockout mice than in wild-type mice [14]. Moreover, many studies show that external application of bFGF promotes wound healing. For example, a study found greatly improved skin hardness with local bFGF injections following lower limb reconstructive surgery with tissue engineering using a tissue scaffold and secondary splitthickness skin graft [15]. Similarly, increased granulation and accelerated epithelialization were observed after treating rat full-thickness acute incisions with bFGF fused to a fibrinbinding peptide (Kringle1) compared with 
Table 3 Clinical studies on the role of bFGF in cutaneous wound management and scar prevention

\begin{tabular}{|c|c|c|c|c|}
\hline Title & $\begin{array}{l}\text { Type of } \\
\text { study }\end{array}$ & Method & $\begin{array}{l}\text { Number } \\
\text { of } \\
\text { subjects }\end{array}$ & Results \\
\hline $\begin{array}{l}\text { Akita et al. } \\
\text { [19] }\end{array}$ & $\begin{array}{l}\text { Randomized } \\
\text { controlled } \\
\text { trial } \\
\text { (RCT) }\end{array}$ & $\begin{array}{l}\text { Clinical assessment of postoperative } \\
\text { color uniformity in split-thickness } \\
\text { skin grafting }\end{array}$ & 40 & $\begin{array}{l}\text { bFGF treatment contributed to a } \\
\text { better color match with skin grafting } \\
\text { postoperatively }\end{array}$ \\
\hline $\begin{array}{l}\text { Morimoto } \\
\text { et al. [20] }\end{array}$ & RCT & $\begin{array}{l}\text { Clinical evaluation of the safety and } \\
\text { efficacy of collagen/gelatin scaffold } \\
\text { impregnated with bFGF ( } 7 \text { or } 14 \mu \mathrm{g} / \\
\mathrm{cm}^{2} \text { ) in the treatment of chronic } \\
\text { skin ulcers after debridement }\end{array}$ & 17 & $\begin{array}{l}\text { In } 16 \text { out of } 17 \text { patients, the wound } \\
\text { bed improved } 14 \text { days after } \\
\text { application without serious adverse } \\
\text { reactions }\end{array}$ \\
\hline $\begin{array}{l}\text { Uchi et al. } \\
\text { [21] }\end{array}$ & RCT & $\begin{array}{l}\text { Clinical assessment of topical bFGF } \\
\text { treatment of non-ischemic diabetic } \\
\text { ulcers for } 8 \text { weeks, in a dose- } \\
\text { dependent manner }\end{array}$ & 150 & $\begin{array}{l}\text { bFGF accelerated wound healing in } \\
\text { diabetic ulcers with } 75 \% \text { or greater } \\
\text { reduction in the area of the wound }\end{array}$ \\
\hline $\begin{array}{l}\text { Akita et al. } \\
\text { [22] }\end{array}$ & RCT & $\begin{array}{l}\text { Clinical assessment of patients } \\
\text { receiving topical bFGF or no bFGF; } \\
\text { outcomes were compared for clinical } \\
\text { scar extent, passive scar hardness, } \\
\text { elasticity, and moisture analysis of } \\
\text { the stratum corneum at } 1 \text { year after } \\
\text { complete wound healing }\end{array}$ & 153 & $\begin{array}{l}\text { Combined use of bFGF and artificial } \\
\text { skin substitute led to improved } \\
\text { wound quality (scars) and facilitated } \\
\text { wound healing }\end{array}$ \\
\hline $\begin{array}{l}\text { Hayashida } \\
\text { et al. [23] }\end{array}$ & RCT & $\begin{array}{l}\text { Clinical evaluation of the effect of } \\
\text { bFGF treatment in pediatric patients } \\
\text { with deep second-degree burn } \\
\text { wounds }\end{array}$ & 20 & $\begin{array}{l}\text { Accelerated healing, reduced scarring, } \\
\text { and improved color matching with } \\
\text { normal skin compared with controls } \\
\text { up to half a year postoperatively }\end{array}$ \\
\hline $\begin{array}{l}\text { Akita et al. } \\
{[15]}\end{array}$ & $\begin{array}{c}\text { Clinical } \\
\text { study }\end{array}$ & $\begin{array}{l}\text { Clinical assessment of sequential lower } \\
\text { extremity reconstruction using an } \\
\text { artificial dermis with or without } \\
\text { bFGF administration, and secondary } \\
\text { split-thickness skin grafting by } \\
\text { measuring hardness using a } \\
\text { durometer, and moisture parameters } \\
\text { for at least } 6 \text { months after the final } \\
\text { procedure and comparison with } \\
\text { normal skin controls }\end{array}$ & 12 & $\begin{array}{l}\text { bFGF-treated sequential artificial } \\
\text { dermis and skin grafting } \\
\text { demonstrated better scarring and } \\
\text { well-organized stratum corneum } \\
\text { after healing }\end{array}$ \\
\hline
\end{tabular}


Table 3 continued

\begin{tabular}{|c|c|c|c|c|}
\hline Title & $\begin{array}{l}\text { Type of } \\
\text { study }\end{array}$ & Method & $\begin{array}{l}\text { Number } \\
\text { of } \\
\text { subjects }\end{array}$ & Results \\
\hline $\begin{array}{l}\text { Ono et al. } \\
{[31]}\end{array}$ & $\begin{array}{l}\text { Prospective } \\
\text { clinical } \\
\text { study }\end{array}$ & $\begin{array}{l}\text { Investigation on bFGF injected into } \\
\text { the dermis of wound margins in full- } \\
\text { thickness wounds in patients } \\
\text { postoperatively after resection of skin } \\
\text { tumors }\end{array}$ & 230 & $\begin{array}{l}\text { Significant reduction of hypertrophic } \\
\text { scarring and widening of remnant } \\
\text { scars without any serious side effects }\end{array}$ \\
\hline $\begin{array}{l}\text { Sugamata } \\
\text { et al. [62] }\end{array}$ & $\begin{array}{r}\text { Clinical } \\
\text { study }\end{array}$ & $\begin{array}{l}\text { Clinical assessment of combined } \\
\text { artificial dermis and application of } \\
\text { Fiblast }{ }^{\circledR} \text { spray in } 6 \text { cases of traumatic } \\
\text { fingertip amputation }\end{array}$ & 6 & $\begin{array}{l}\text { The shapes of the fingertips were } \\
\text { satisfactorily reconstructed in all } \\
\text { patients }\end{array}$ \\
\hline $\begin{array}{l}\text { Matsumoto } \\
\text { et al. [72] }\end{array}$ & $\begin{array}{c}\text { Clinical } \\
\text { study }\end{array}$ & $\begin{array}{l}\text { Examination of the safety of bFGF- } \\
\text { impregnated gelatin application for } \\
\text { patients }\end{array}$ & 4 & $\begin{array}{l}\text { The findings suggested that controlled- } \\
\text { release bFGF using gelatin sheet is } \\
\text { effective for promoting wound } \\
\text { healing }\end{array}$ \\
\hline $\begin{array}{l}\text { Saijo et al. } \\
\text { [82] }\end{array}$ & Case reports & $\begin{array}{l}\text { Application of combined treatment of } \\
\text { artificial dermis and bFGF to treat } \\
\text { cranial bone-exposing wounds } \\
\text { followed by free skin grafting }\end{array}$ & 2 & $\begin{array}{l}\text { The formation of granulation tissue } \\
\text { was promoted and acted as a wound } \\
\text { bed for the subsequent skin grafting }\end{array}$ \\
\hline $\begin{array}{l}\text { Kurokawa } \\
\text { et al. [83] }\end{array}$ & Case report & $\begin{array}{l}\text { Topical application of bFGF to } \\
\text { chronic leg ulcers at a dose of } \\
30 \mu \mathrm{g} / \text { day for } 3 \text { months }\end{array}$ & 1 & $\begin{array}{l}\text { The ulcer area was reduced by } \\
\text { promoted angiogenesis, re- } \\
\text { epithelization, granulation and scar } \\
\text { formation }\end{array}$ \\
\hline $\begin{array}{c}\text { Asai et al. } \\
{[84]}\end{array}$ & Case report & $\begin{array}{l}\text { Topical application of a mixture of } \\
\text { peripheral blood mononuclear cells } \\
\text { (PBMC) and bFGF to diabetic foot } \\
\text { ulcer }\end{array}$ & 1 & $\begin{array}{l}\text { The ulcer was completely closed and no } \\
\text { new ulceration recurred after } \\
6 \text { months follow-up }\end{array}$ \\
\hline $\begin{array}{c}\text { Ito et al. } \\
{[85]}\end{array}$ & Case report & $\begin{array}{l}\text { Combined application of bilayer } \\
\text { artificial dermis graft and bFGF } \\
\text { without secondary skin grafts or flaps } \\
\text { to large soft tissue defect of the heel } \\
\text { after a degloving injury }\end{array}$ & 1 & $\begin{array}{l}\text { bFGF induced wound closure and } \\
\text { successful reconstruction without } \\
\text { sacrificing skin from donor sites }\end{array}$ \\
\hline $\begin{array}{l}\text { Akita et al. } \\
{[86]}\end{array}$ & Case report & $\begin{array}{l}\text { Simultaneous application of bFGF } \\
\text { with regular surgical debridement } \\
\text { and skin grafting was investigated for } \\
\text { skin hardness by clinical examination } \\
\text { and instrumental measurement }\end{array}$ & 1 & $\begin{array}{l}\text { Wounds treated with bFGF produced } \\
\text { scars that were significantly less hard } \\
1 \text { year after final wound closure }\end{array}$ \\
\hline
\end{tabular}


Table 3 continued

\begin{tabular}{|c|c|c|c|c|}
\hline Title & $\begin{array}{l}\text { Type of } \\
\text { study }\end{array}$ & Method & $\begin{array}{l}\text { Number } \\
\text { of } \\
\text { subjects }\end{array}$ & Results \\
\hline $\begin{array}{l}\text { Muneuchi } \\
\text { et al. [87] }\end{array}$ & Case reports & $\begin{array}{l}0.1 \mathrm{~mL} \text { of bFGF (Fiblast }{ }^{\circledR} \text { ) was } \\
\text { injected into the sutured collagen } \\
\text { layer of artificial dermis followed by } \\
\text { daily injection of bFGF for } 2 \text { weeks, } \\
\text { topical ointment with recombinant } \\
\text { bFGF was then continued }\end{array}$ & 2 & $\begin{array}{l}\text { The wound was completely } \\
\text { epithelialized } 10 \text { weeks after injury } \\
\text { with good sensory recovery }\end{array}$ \\
\hline $\begin{array}{l}\text { Yamaka } \\
\text { et al. [88] }\end{array}$ & Case report & $\begin{array}{l}\text { Topical application of rhbFGF } \\
30 \mu \mathrm{g} / \text { daily in combination with } \\
\text { prostaglandin E1 ointment applied } \\
\text { directly to therapy-resistant chronic } \\
\text { leg ulcers in scleroderma }\end{array}$ & 1 & $\begin{array}{l}\text { The lesions were completely re- } \\
\text { epithelialized within } 20 \text { days and the } \\
\text { ulcers did not recur during the } \\
\text { 20-month follow-up period }\end{array}$ \\
\hline
\end{tabular}

positive controls. The authors also noted that after subcutaneous implantation, a fibrin scaffold suffused with the Kringle1-bFGF fusion protein efficiently induced local angiogenesis, indicating that this approach was also useful for wounds deficient in plasma clot formation [16].

In addition, bFGF treatment of incisional wounds in diabetic rats was found to improve epithelialization, granulation, and woundbreaking strength to levels observed in non-diabetic mice [17].

Several RCTs have been conducted in Japan to examine the efficacy and safety of bFGF in treating chronic skin ulcers, diabetic ulcers, and venous ulcers. An RCT on the utility of Fiblast ${ }^{\circledR}$ spray to improve healing of ulcers or seconddegree burns after debridement and split thickness skin grafting revealed that applying bFGF immediately after debridement and before grafting significantly improved scar quality and graft color match $[18,19]$.

Furthermore, a first-in-human RCT evaluated the utility of an artificial dermis with sustainedrelease bFGF to improve healing of chronic skin ulcers. The artificial dermis comprising a collagen/gelatin sponge was designed to release bFGF for $>10$ days. The patients were randomized to application of either a low-dose $(7 \mathrm{mg} /$ $\mathrm{cm}^{2}$ bFGF impregnation) or high-dose (14 mg/ $\mathrm{cm}^{2}$ bFGF impregnation) preparation after wound debridement. The degree of wound improvement was assessed 14 days after the sponge was applied. Of the 17 patients divided into the two low- and high-dose groups, 16 demonstrated significant wound improvement, as indicated by the granulation and epithelialization that reduced the wound area by $\geq 50 \%$. No serious adverse effects were reported [20]. Moreover, a placebo-controlled RCT assessed the ability of topical $0.001 \%$ (50 mg) or $0.01 \%$ $(500 \mathrm{mg}) \mathrm{bFGF}$ application for up to 8 weeks to improve healing of non-ischemic diabetic ulcers. The low- and high-dose treatments reduced the wound area by $>75 \%$ in $72.3 \%$ and $82.2 \%$ of the patients, respectively. In contrast, this reduction was only seen in $57.5 \%$ of the placebo-treated patients. Thus, bFGF treatment accelerated diabetic ulcer healing [21]. In addition, bFGF treatment was found to improve healing of partial thickness skin burns in two RCTs. The first trial was in adult patients; 119 wounds were treated with topical $1 \mu \mathrm{g} / \mathrm{cm}^{2}$ bFGF, while 122 wounds received standard care. The bFGF-treated wounds closed on average 3 days earlier than the control wounds. The second trial was in pediatric patients who were treated with the same regimen used in the adults; the 15 treated wounds closed on average 3.7 days before the control wounds $[22,23]$. 


\section{Local bFGF Treatment Prevents Pathological Scar Formation}

Scarring is influenced by multiple factors, and this accounts for the wide variations of the different clinical types of scars. These range from typical flat white scars, sunken atrophic scars, and aggressively growing fibroproliferative pathological scars, namely, keloids and hypertrophic scars [24].

These pathological scars often develop following trauma and burn injuries and are quite common; in the US alone about 40 million cases of pathological scars are reported every year [25]. Over the past decade, findings from clinical and animal studies have greatly improved our understanding of the pathogenesis of keloids and hypertrophic scars, particularly that their development and progression is driven by chronic inflammation [26]. This knowledge has facilitated the development of therapies that prevent or reduce pathological scarring and act at least in part by blocking or ameliorating wound/scar inflammation. These include silicone tape, compression garment therapy, steroid injections, laser therapy, cryosurgery, radiotherapy, and surgical excision [26-30]. However, because pathological scars remain difficult to treat, there are continued ongoing research efforts to develop new therapies to prevent their formation. In Japan, studies showing that bFGF accelerates wound healing and smooth epithelialization have led to considerations that local application of bFGF could also prevent the formation of pathological scars in trauma and burn injuries. This hypothesis was supported by a report where immediate rinsing with or injection of bFGF into sutured incisional wounds following resection of skin tumors significantly reduced the likelihood of developing hypertrophic scars or scar widening after healing versus untreated control wounds [31]. Also, repeated bFGF treatment started soon after wounding for formed hypertrophic scars in full-thickness excisional wounds in rabbit ears greatly decreased pathological scarring as shown by significant reductions in scar elevation and epidermal thickness indices [32].

\section{Local bFGF Treatment May Reduce Pre- existing Pathological Scars}

Some evidence suggests that bFGF treatment could also reduce pre-existing pathological scars. Eto et al. showed that implanting human hypertrophic scars onto nude mice and treating the scars with a controlled-release bFGF formulation decreased the size of the scars. The hydroxyproline content also decreased, and collagen fiber degradation was observed. Thus, bFGF induced collagen degradation in hypertrophic scars. This observation was supported by the fact that bFGF treatment upregulated matrix metalloproteinase-1 expression in fibroblasts from hypertrophic scars, but not in fibroblasts from normal dermis [33]. Also, there is some evidence that bFGF could induce myofibroblast apoptosis. Funato et al. reported that converting palatal fibroblasts into myofibroblasts followed by treatment with bFGF resulted in apoptosis. Interestingly, they showed that compared to normal palatal fibroblasts, myofibroblasts from palatal scars are more sensitive to bFGF, as shown by the greater tyrosine autophosphorylation of their bFGF receptors [34].

\section{Cellular Mechanism and Signaling Pathways of bFGF}

\section{Local bFGF Treatment Accelerates Wound Healing by Several Cellular Mechanisms}

The mechanisms underlying these wound healing effects of bFGF reflect the multiple properties of this glycoprotein. Specifically, due to its strong mitogenic properties, bFGF accelerates the division and proliferation of cells in the wound bed, namely, endothelial cells, dermal fibroblasts, and keratinocytes. Moreover, its chemoattractant properties influence the migration of these cells during wound healing, thereby promoting neovascularization and epithelialization. In addition, bFGF attracts leukocytes to the wound, thus helping to initiate the inflammatory phase of wound healing. It also strongly stimulates the production and metabolism of major extracellular macromolecules such as collagen, tropoelastin, and 
hyaluronic acid by fibroblasts, thereby shaping scar tissue maturation [35].

\section{bFGF Signaling Pathways that Participate in Wound Healing}

bFGF is known to efficiently promote fibroblast proliferation and migration $[36,37]$. The effects of bFGF on signaling pathways that drive these and other important fibroblast functions in normal and abnormal wound healing remain incompletely understood. However, there are several lines of evidence suggesting that FGFs, and in particular bFGF, activate other signaling pathways in fibroblasts, as follows.

In relation to the signaling initiated in fibroblasts by bFGF exclusively, in vitro and in vivo studies show that bFGF accelerates human fibroblast migration by independently activating the PI3K/Rac1/JNK pathway [38]. This is supported by several studies on cultured human dermal fibroblasts, which show that bFGF treatment induces fibroblast migration by significantly increasing Akt, Rac1, and JNK activity $[39,40]$. Moreover, Shi et al. showed that reactive oxygen species (ROS) are a key component in this cascade of events [41]. These findings led to proposing the notion that bFGF promotes the migration of human dermal fibroblasts by binding to and activating FGFR, which stimulates Akt. This drives the phosphorylation of Rac1, which activates both JNK and NOX [41]. Both events then lead to the production of ROS, which activates FAK and paxillin, in turn inducing the cytoskeletal rearrangement needed for fibroblast migration (Fig. 2) [41, 42].

\section{bFGF Could Prevent Pathological Scarring by Various Mechanisms}

Regulating ECM Synthesis and Degradation bFGF may prevent excessive dermal deposition of collagen, which plays a crucial role in the development and progression of keloids and hypertrophic scars. This deposition is the result of an imbalance between collagen synthesis and degradation that leads to a disorganized and voluminous fiber structure in the dermis [43, 44]. While collagen deposition is a necessary part of normal wound healing, excessive deposition causes pathological scarring $[45,46]$. Because bFGF treatment accelerates the appropriate deposition and distribution of collagen in wounds [47-49], the application of bFGF to the injured area soon after wounding

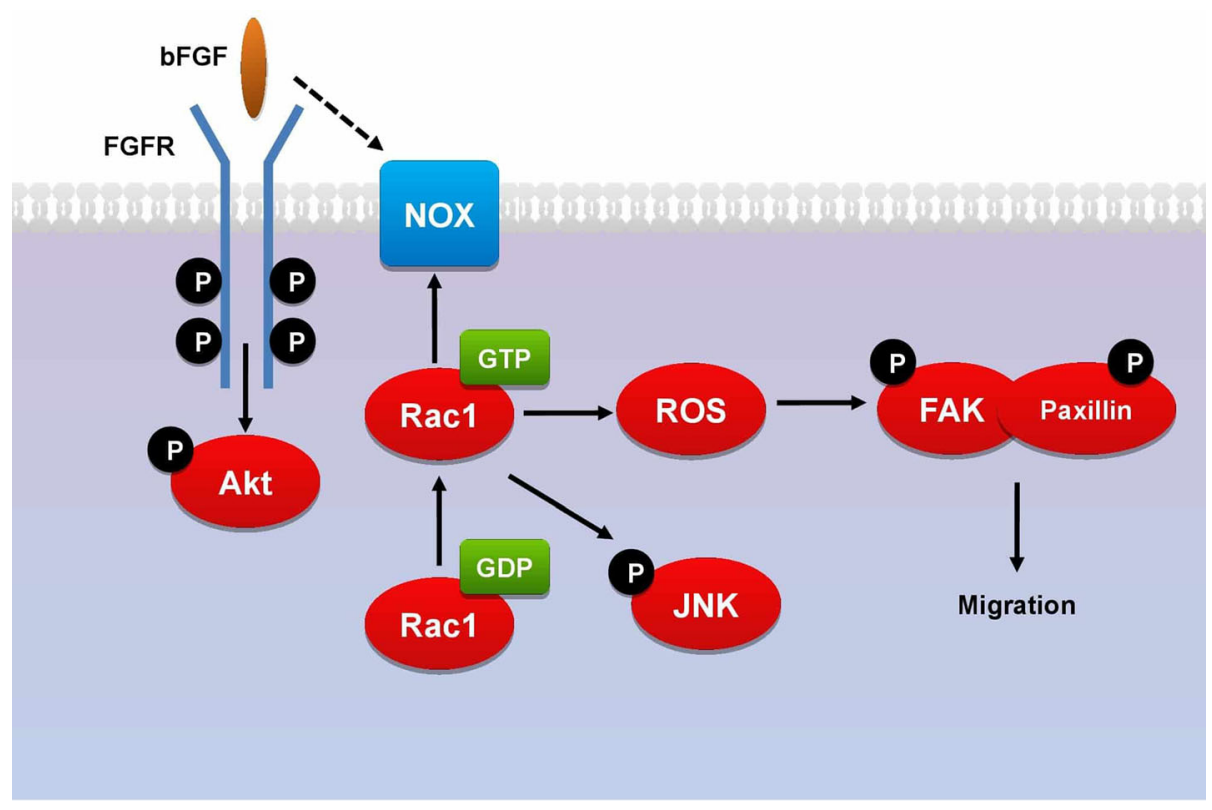

Fig. 2 Proposed signaling pathway of bFGF in promoting the migration of human dermal fibroblasts by activating PI3K/ Akt-Rac1-FAK-JNK signaling, which induces the cytoskeletal rearrangement needed for fibroblast migration 
may hasten the appropriate development of the ECM in the wound, and this effect of local bFGF may help to prevent the onset of the chronic inflammation that drives pathological scarring.

\section{Inducing Apoptosis of Granulation-Tissue} Fibroblasts bFGF treatment was reported to reduce collagen density, decrease expression of fibronectin, tissue inhibitor of metalloproteinase-1, collagen I, and collagen III, and increase expression of matrix metalloproteinase-1 in ear wounds. bFGF also increased apoptosis of fibroblasts in granulation tissue [32]. This is consistent with a report where bFGF treatment induced apoptosis in granulationtissue fibroblasts. In contrast, bFGF had no effect on fibroblasts from uninjured dermis, suggesting that bFGF might inhibit scar formation by promoting programmed cell death of fibroblasts in granulation tissue throughout the remodeling stage of wound healing [50].

\section{Interfering with Myofibroblast Forma-} tion bFGF may also prevent pathological scarring by interfering with the formation of myofibroblasts, which is considered the most important mechanism underlying the development of keloids and hypertrophic scars. Myofibroblasts are activated collagen-hypersecreting cells that differentiate terminally from the normally quiescent dermis-derived cells (particularly dermal fibroblasts) into activated collagenhypersecreting myofibroblasts. This event occurs by a process called endothelial/epithelial to mesenchymal transition (EMT). Formation of myofibroblasts is the most important mechanism underlying the development of keloids and hypertrophic scars [36]. Indeed, Tiede et al. showed that multipotent human dermisderived progenitor cells tend to differentiate into myofibroblasts in the presence of serum and that co-culture with bFGF inhibits this mesodermal differentiation; bFGF-cocultured cells expressed much lower levels of the myofibroblast marker alpha-smooth muscle actin $(\alpha-$ SMA) than control cells [36]. It is likely that this effect of bFGF is also mediated by the ability of this cytokine to inhibit the TGF $\beta 1 /$ SMAD-dependent pathway, and the study of Shi et al. in hypertrophic rabbit ear showed that topical application of bFGF downregulated $\alpha$-SMA expression as well as TGF $\beta 1 /$ SMAD signaling [32]. This is believed to be initiated through the expression of miR-20a, which in turn represses the expression of the TGF $\beta$ receptor complex (ALK5 and TGFBR2) and SARA, thus inhibiting Smad2 and Smad3 activation, which plays an important role in the development of fibroproliferative disorders (Fig. 3) [51].

Finally, bFGF may impede pathological scarring by promoting fibroblast proliferation $[37,52]$. It may also act by enhancing fibroblast migration. Kanazawa et al. showed that bFGF promoted the migration of fibroblasts when the proliferation of these cells was blocked by mitomycin C treatment [53].

\section{Effect of bFGF on Non-fibroblast Cell Types}

The findings described above show that bFGF promotes fibroblast migration and perhaps proliferation, differentiation, and survival of these cells also. It should be noted that the name fibroblast growth factor (FGF) reflects the fact that these molecules were initially known for these effects on fibroblasts. However, it was later shown that FGFs were identical to endothelial cell growth factors [54, 55]. Thus, FGFs do not act specifically on fibroblasts. Moreover, several animal studies showed that bFGF affects not only fibroblast and endothelial cell functions [56, 57], but also influences keratinocyte proliferation and migration $[58,59]$, nerve regeneration [60], and vascular smooth muscle cell proliferation [61].

\section{Methods of bFGF Delivery for Improving Wound Healing}

In Japan, hrbFGF preparation Fiblast ${ }^{\circledR}$ spray has been used as a topical spray to improve wound healing by directly spraying it onto the wound area. This is then followed by applying a standard dressing. Its efficacy in this formulation is demonstrated in a study by Sugamata et al. where the healing period was shortened and good reconstruction of the fingertip shapes was achieved in amputated human fingertips 


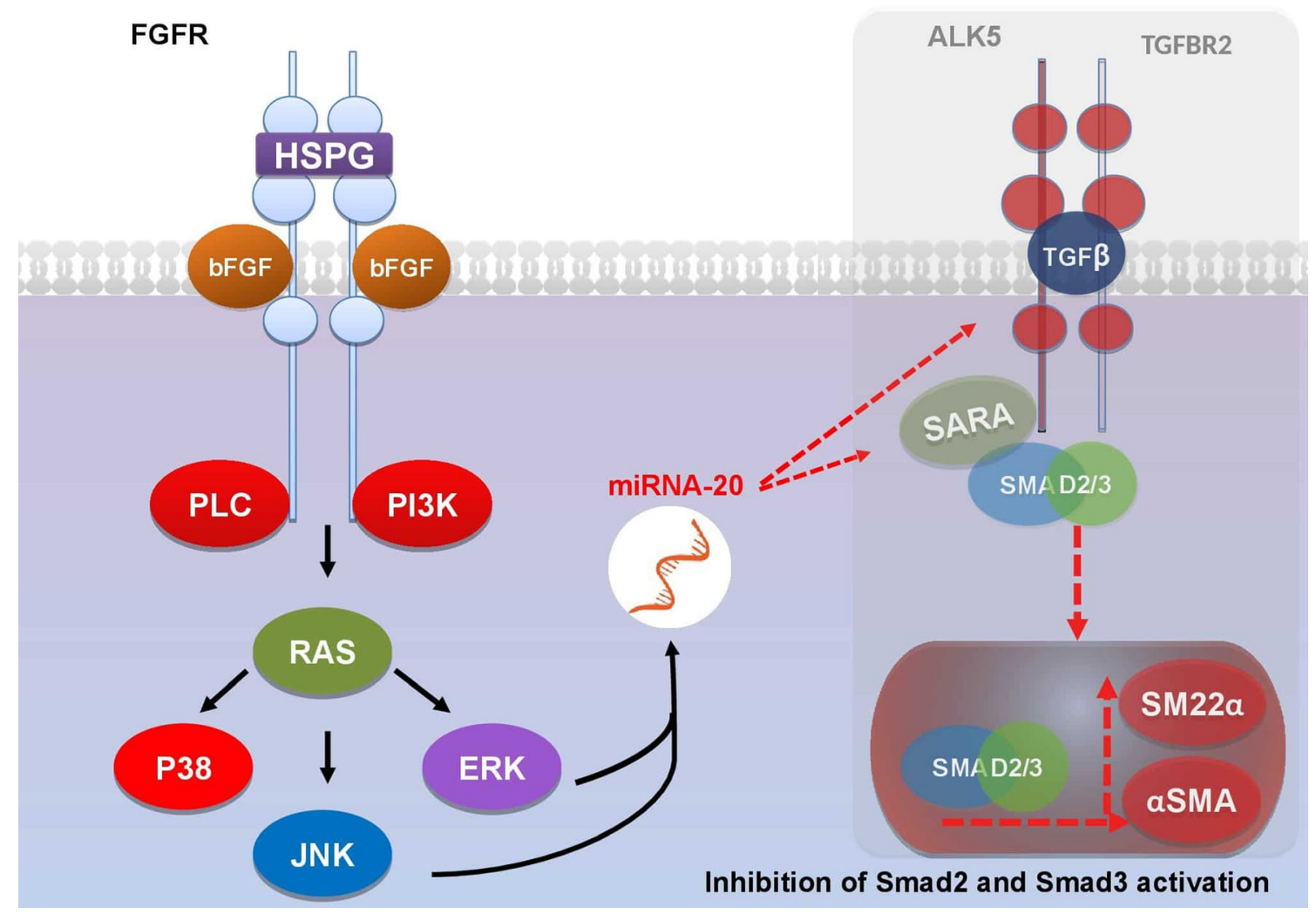

Fig. 3 bFGF downstream mediators Ras and PI3K activate miR-20a expression, which in turn inhibits the expression of the TGF $\beta$ receptor complex (ALK5 and

reconstructed with artificial dermis and then treated with Fiblast ${ }^{\circledR}$ spray [62].

Currently, Fiblast ${ }^{\circledR}$ spray is routinely used throughout Japan for negative pressure wound therapy. This combination therapy became available after the Japanese national health insurance system coverage of the use of the V.A.C. ATS ${ }^{\circledR}$ Negative Pressure Wound Therapy System (Kinetic Concepts, Inc., Tokyo, Japan). This widespread use of the Fiblast ${ }^{\circledR}$ spray is emblematic of its considerable effectiveness in wound healing.

\section{Controlled Release of bFGF Is Associated with Increased Efficacy}

Free bFGF is water soluble and is rapidly degraded in vivo. Thus, it has a short half-life [63]. Therefore, various formulations have been developed to prevent this degradation. Xiang et al. showed that bFGF-encapsulated liposomes (bFGF-lip) improved healing of deep second-
TGFBR2) and SARA, thus blocking the Smad2 and Smad3 activation, which plays an important role in the development of fibroproliferative disorders

degree burns in rats relative to treatment with blank liposomes [64]. Similarly, another study by the Department of Plastic and Reconstructive Surgery in the Graduate School of Medicine of Kyoto University showed that artificial dermis with incorporated biodegradable gelatin bFGFcontaining microspheres when implanted into full-thickness skin defects in guinea pigs accelerated fibroblast proliferation and wound angiogenesis [65]. Further experiments by this group showed that implantation of murine fullthickness skin wounds with bFGF-impregnated collagen/gel sponges greatly accelerated the formation of dermis-like tissue [66]. This group also found that similar treatment of debrided decubitus ulcers in diabetic mice accelerated wound closure, epithelialization, and angiogenesis [67]. Thus, this group began an investigator-initiated first-in-human RCT in 2010 to examine the effects of this approach in patients with persistent ulcers. The findings were 


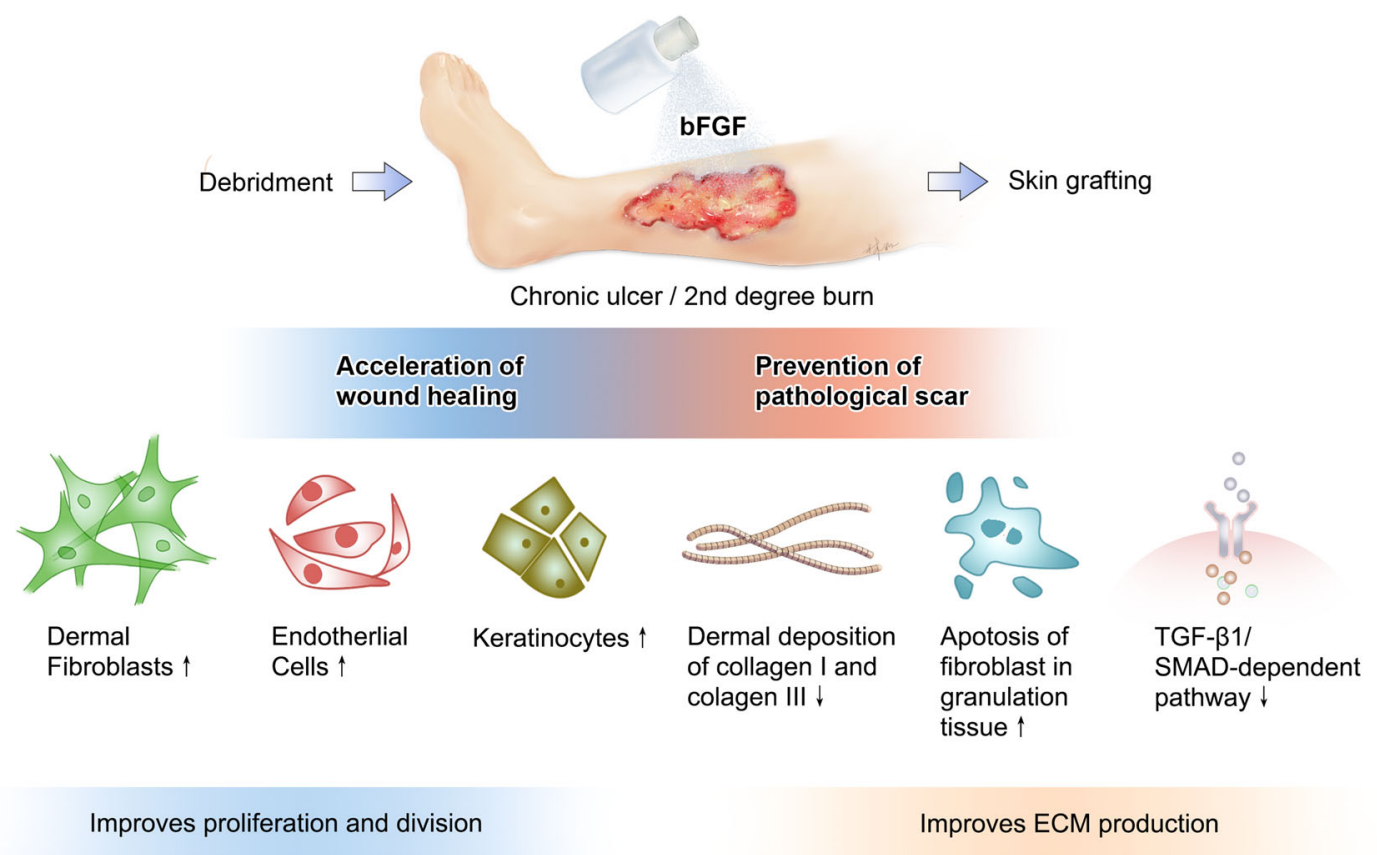

Fig. 4 Illustrative overview of the biological actions of bFGF application in chronic ulcer and burn injury involved in accelerating wound healing and preventing pathological scar development

reported in 2013 as described previously. Briefly, an artificial dermis consisting of a collagen/gelatin sponge with sustained release of bFGF for > 10 days significantly improved chronic ulcer healing [20].

Another group examined the effect of implanting a controlled-release bFGF-impregnated gelatin hydrogel in mouse incisions. This innovative approach significantly increased neovascularization when subcutaneously implanted in the back of the mice $[68,69]$. This early study showed that a gelatin scaffold could release a single growth factor or drug in a controlled fashion, thereby increasing the efficacy of the active agent in wound healing.

\section{Fiblast $^{\circledast}$ Spray vs. bFGF-impregnated Gelatin Sheet}

In contrast with studies reporting the effectiveness of bFGF in accelerating wound healing, a study has shown no significant difference between bFGF-chitosan film compared with chitosan film only when applied to surgically created full-thickness wounds in diabetic mice [70]. Additionally, a pilot, randomized, doubleblind study compared the topical application of
bFGF with placebo in 17 diabetic patients with neurotrophic foot ulcers and reported similar outcomes of bFGF and placebo for healing chronic diabetic ulcer of the foot. Thus, it was hypothesized that using a single growth factor such as bFGF alone might be insufficient for healing of such severe wounds [71].

The effectiveness of the bFGF-impregnated gelatin sheet was compared with conventional spray administered in a murine model for wound healing. Compared with the bFGF spray group, the bFGF-gelatin group demonstrated significantly better wound healing outcomes including faster wound closure, greater area of mature collagen at the early stage of wound healing, and higher vascular density. This suggests that bFGF-impregnated gelatin sheet yields a better acceleration effect on wound healing compared with bFGF spray [72].

There is now considerable evidence showing that bFGF accelerates healing of a wide range of wounds, including pressure ulcers, second degree burns, leg ulcers, and diabetic ulcers, in addition to prevention of scar formation. A large body of research also indicates that bFGF effectively accelerates the process of wound 
healing and can prevent the development of pathological scars as illustrated in Fig. 4 . This is as a result of stimulating the proliferation, differentiation, and migration of fibroblasts and endothelial cells and keratinocytes in the skin, in addition to regulating ECM production and metabolism as previously discussed. These potent effects on key cellular players in wound healing account for the widespread routine use of the commercially available rhbFGF preparation Fiblast ${ }^{\circledR}$ spray to promote wound healing and prevent fibroproliferative scarring in the clinical setting throughout Japan.

This study has some limitations. First, the review was restricted to the Japanese literature and as such may not reflect research findings abroad. Second, the list of keywords used for retrieving articles in the PubMed database search was incomplete and thus may not represent the full range of such studies. Third, the majority of the studies were animal studies and so are not representative of clinical applicability. Hence, further translational research is needed.

\section{CONCLUSION}

In the 2 decades since Fiblast ${ }^{\circledR}$ spray was launched in Japan, several other bFGF delivery systems have been developed, including controlled-release bFGF formulations such as bFGF gelatin sheets. Further research on these alternative formulations is needed to clarify additional clinical advantages, including greater convenience and lower treatment costs, while simultaneously efficiently improving wound healing and reducing the risk of post-surgical scar formation.

\section{ACKNOWLEDGEMENTS}

Funding. No funding or sponsorship was received for this study or publication of this article.

Authorship. All named authors meet the International Committee of Medical Journal
Editors (ICMJE) criteria for authorship for this article, take responsibility for the integrity of the work as a whole, and have given their approval for this version to be published.

Disclosures. Mohamed Abdelhakim, Xunxun Lin, and Rei Ogawa have nothing to disclose. Rei Ogawa is a member of the journal's Editorial Board.

Compliance with Ethics Guidelines. This article is based on previously conducted studies and does not contain any studies with human participants or animals performed by any of the authors.

Data Availability. Data sharing is not applicable to this article as no datasets were generated or analyzed during the current study.

Open Access. This article is licensed under a Creative Commons Attribution-NonCommercial 4.0 International License, which permits any non-commercial use, sharing, adaptation, distribution and reproduction in any medium or format, as long as you give appropriate credit to the original author(s) and the source, provide a link to the Creative Commons licence, and indicate if changes were made. The images or other third party material in this article are included in the article's Creative Commons licence, unless indicated otherwise in a credit line to the material. If material is not included in the article's Creative Commons licence and your intended use is not permitted by statutory regulation or exceeds the permitted use, you will need to obtain permission directly from the copyright holder. To view a copy of this licence, visit http://creativecommons.org/licenses/by$\mathrm{nc} / 4.0 /$.

\section{REFERENCES}

1. Park JW, Hwang SR, Yoon IS. Advanced growth factor delivery systems in wound management and skin regeneration. Molecules. 2017;22:E1259.

2. Trengove NJ, Bielefeldt-Ohmann H, Stacey MC. Mitogenic activity and cytokine levels in non- 
healing and healing chronic leg ulcers. Wound Repair Regen. 2000;8:13-25.

3. Brown LF, Yeo KT, Berse B, et al. Expression of vascular permeability factor (vascular endothelial growth factor) by epidermal keratinocytes during wound healing. J Exp Med. 1992;176:1375-9.

4. Powers CJ, McLeskey SW, Wellstein A. Fibroblast growth factors, their receptors and signaling. Endocr Relat Cancer. 2000;7:165-97.

5. Price EW, Carnazza KE, Carlin SD, et al. 89Zr-DFOAMG102 immuno-PET to determine local hepatocyte growth factor protein levels in tumors for enhanced patient selection. J Nucl Med. 2017;58: 1386-94.

6. Yoshida K, Nakachi K, Imai K, et al. Lung cancer susceptibility among atomic bomb survivors in relation to CA repeat number polymorphism of epidermal growth factor receptor gene and radiation dose. Carcinogenesis. 2009;30:2037-41.

7. Hayes CS, Defeo K, Dang H, et al. A prolonged and exaggerated wound response with elevated ODC activity mimics early tumor development. Carcinogenesis. 2011;32:1340-8.

8. Turner N, Grose R. Fibroblast growth factor signalling: from development to cancer. Nat Rev Cancer. 2010;10(2):116-29.

9. Carter EP, Fearon AE, Grose RP. Careless talk costs lives: fibroblast growth factor receptor signalling and the consequences of pathway malfunction. Trends Cell Biol. 2015;25:221-33.

10. Wu X, Su Z, Zheng Q, Huang Y, Li X. Expression and activity identification of shortened human acidic fibroblast growth factor. J China Pharm Univ. 2004;35:470-3.

11. Yao C, Zheng $\mathrm{Q}, \mathrm{Xu} \mathrm{H}$, et al. The stability of recombinant human acid fibroblast growth factor. Chin J Mod Appl Pharm. 2006;23:358-60.

12. Zhao J, Fu X, Chen C. The wild-type aFGF has been shown to significantly induce the cutaneous cell proliferation, whereas the truncated aFGF, which had been truncated the N-terminal sequence "21NYKKPKL27", had no apparent impact on cell proliferation, which may reduce the effect of aFGF on the induction of tumour. Chin Crit Care Med. 2004;16:458-9.

13. Fu X, Shen Z, Chen Y, Xie J, Guo Z, Zhang M, Sheng $Z$. Recombinant bovine basic fibroblast growth factor accelerates wound healing in patients with burns, donor sites and chronic dermal ulcers. Chin Med J. 2000;113(4):367-71.
14. Ortega S, Ittmann M, Tsang SH, Ehrlich M, Basilico C. Neuronal defects and delayed wound healing in mice lacking fibroblast growth factor 2. Proc Natl Acad Sci. 1998;95(10):5672-7.

15. Akita S, Akino K, Tanaka K, Anraku K, Hirano A. A basic fibroblast growth factor improves lower extremity wound healing with a porcine-derived skin substitute. J Trauma. 2008;64:809-15.

16. Zhao W, Han Q, Lin $\mathrm{H}$, et al. Improved neovascularization and wound repair by targeting human basic fibroblast growth factor (bFGF) to fibrin. J Mol Med (Berl). 2008;86(10):1127-38.

17. Tsuboi R, Rifkin DB. Recombinant basic fibroblast growth factor stimulates wound healing in healingimpaired db/db mice. J Exp Med. 1990;172:245-51.

18. Akita S, Akino K, Hirano A. Basic fibroblast growth factor in scarless wound healing. Adv Wound Care (New Rochelle). 2013;2(2):44-9.

19. Akita S, Akino K, Yakabe A, et al. Basic fibroblast growth factor is beneficial for postoperative color uniformity in split-thickness skin grafting. Wound Repair Regen. 2010;18(6):560-6.

20. Morimoto N, Yoshimura K, Niimi M, et al. Novel collagen/gelatin scaffold with sustained release of basic fibroblast growth factor: clinical trial for chronic skin ulcers. Tissue Eng Part A. 2013;19(17-18):1931-40.

21. Uchi H, Igarashi A, Urabe K, et al. Clinical efficacy of basic fibroblast growth factor (bFGF) for diabetic ulcer. Eur J Dermatol. 2009;19(5):461-8.

22. Akita S, Akino K, Imaizumi T, Hirano A. Basic fibroblast growth factor accelerates and improves second-degree burn wound healing. Wound Repair Regen. 2008;16(5):635-41.

23. Hayashida K, Akita S. Quality of pediatric seconddegree burn wound scars following the application of basic fibroblast growth factor: results of a randomized, controlled pilot study. Ostomy Wound Manag. 2012;58(8):32-6.

24. Bloemen MC, van der Veer WM, Ulrich MM, et al. Prevention and curative management of hypertrophic scar formation. Burns. 2009;35:463-75.

25. Levinson $\mathrm{H}$. A paradigm of fibroblast activation and dermal wound contraction to guide the development of therapies for chronic wounds and pathologic scars. Adv Wound Care (New Rochelle). 2013;2(4):149-59.

26. Ogawa R. Keloid and hypertrophic scars are the result of chronic inflammation in the reticular dermis. Int J Mol Sci. 2017;18(3):606. 
27. Aarabi S, Longaker MT, Gurtner GC. Hypertrophic scar formation following burns and trauma: new approaches to treatment. PLoS Med. 2007;4:e234.

28. Niessen FB, Spauwen PH, Robinson PH, Fidler V, Kon M. The use of silicone occlusive sheeting (Sil-K) and silicone occlusive gel (Epiderm) in the prevention of hypertrophic scar formation. Plast Reconstr Surg. 1998;102:1962-72.

29. Ward RS. Pressure therapy for the control of hypertrophic scar formation after burn injury. A history and review. J Burn Care Rehabil. 1991;12: 257-62.

30. Van der Veer WM, Ferreira JA, de Jong EH, Molema G, Niessen FB. Perioperative conditions affect longterm hypertrophic scar formation. Ann Plast Surg. 2010;65:321-5.

31. Ono I, Akasaka Y, Kikuchi R, et al. Basic fibroblast growth factor reduces scar formation in acute incisional wounds. Wound Repair Regen. 2007;15(5): 617-23.

32. Shi H-X, Lin C, Lin B-B, et al. The anti-scar effects of basic fibroblast growth factor on the wound repair in vitro and in vivo. PLoS One. 2013;8(4):e59966.

33. Eto H, Suga H, Aoi N, et al. Therapeutic potential of fibroblast growth factor-2 for hypertrophic scars: upregulation of MMP-1 and HGF expression. Lab Investig. 2012;92(2):214-23.

34. Funato N, Moriyama K, Shimokawa H, Kuroda T. Basic fibroblast growth factor induces apoptosis in myofibroblastic cells isolated from rat palatal mucosa. Biochem Biophys Res Commun. 1997;240: 21-6.

35. Welham NV, Montequin DW, Tateya I, Tateya T, Choi SH, Bless DM. A rat excised larynx model of vocal fold scar. J Speech Lang Hear Res. 2009;52: 1008.

36. Tiede S, Ernst N, Bayat A, Paus R, Tronnier V, Zechel C. Basic fibroblast growth factor: a potential new therapeutic tool for the treatment of hypertrophic and keloid scars. Ann Anat. 2009;191:33.

37. Iyer VR, Eisen MB, Ross DT, et al. The transcriptional program in the response of human fibroblasts to serum. Science. 1999;283:83-7.

38. Xuan Y, Chi L, Tian H, et al. The activation of the NF-kappaB-JNK pathway is independent of the PI3K-Rac1-JNK pathway involved in the bFGF-regulated human fibroblast cell migration. J Dermatol Sci. 2016;82(1):28-37.

39. Xuan YH, Huang BB, Tian HS, et al. High-glucose inhibits human fibroblast cell migration in wound healing via repression of bFGF-regulating JNK phosphorylation. PLoS One. 2014;9(9):e108182.

40. Wang X, Zhu Y, Sun C, et al. Feedback activation of basic fibroblast growth factor signaling via the Wnt/ $\beta$-Catenin pathway in skin fibroblasts. Front Pharmacol. 2017;8:32.

41. Shi $\mathrm{H}$, Cheng $\mathrm{Y}$, Ye J, et al. bFGF promotes the migration of human dermal fibroblasts under diabetic conditions through reactive oxygen species production via the PI3K/Akt-Rac1- JNK pathways. Int J Biol Sci. 2015;11(7):845-59.

42. Teven CM, Farina EM, Rivas J, Reid RR. Fibroblast growth factor (FGF) signaling in development and skeletal diseases. Genes Dis. 2014;1(2):199-213.

43. Sidgwick GP, Bayat A. Extracellular matrix molecules implicated in hypertrophic and keloid scarring. J Eur Acad Dermatol Venereol. 2012;26: 141-52.

44. Oliveira GV, Hawkins HK, Chinkes D, et al. Hypertrophic versus non hypertrophic scars compared by immunohistochemistry and laser confocal microscopy: type I and III collagens. Int Wound J. 2009;6:445-52.

45. Colwell AS, Phan TT, Kong W, Longaker MT, Lorenz $\mathrm{PH}$. Hypertrophic scar fibroblasts have increased connective tissue growth factor expression after transforming growth factor-beta stimulation. Plast Reconstr Surg. 2005;116(5):1387-92.

46. Verhaegen PD, Marle JV, Kuehne A, Schouten HJ, Gaffney EA, et al. Collagen bundle morphometry in skin and scar tissue: a novel distance mapping method provides superior measurements compared to Fourier analysis. J Microsc. 2012;245(1):82-9.

47. Ortega S, Ittmann M, Tsang SH, et al. Neuronal defects and delayed wound healing in mice lacking fibroblast growth factor 2. Proc Natl Acad Sci USA. 1998;95(10):5672-7.

48. McGee GS, Davidson JM, Buckley A, et al. Recombinant basic fibroblast growth factor accelerates wound healing. J Surg Res. 1988;45(1):145-53.

49. Hebda PA, Klingbeil CK, Abraham JA, et al. Basic fibroblast growth factor stimulation of epidermal wound healing in pigs. J Invest Dermatol. 1990;95(6):626-31.

50. Akasaka Y, Ono I, Kamiya T, et al. The mechanisms underlying fibroblast apoptosis regulated by growth factors during wound healing. J Pathol. 2010;221(3):285-99.

51. Correia AC, Moonen JR, Brinker MG, Krenning G. FGF2 inhibits endothelial-mesenchymal transition 
through microRNA-20a-mediated repression of canonical TGF- $\beta$ signaling. J Cell Sci. 2016;129(3): 569-79.

52. Schreier $\mathrm{T}$, Degen E, Baschong W. Fibroblast migration and proliferation during in vitro wound healing. A quantitative comparison between various growth factors and a low molecular weight blood dialysate used in the clinic to normalize impaired wound healing. Res Exp Med. 1993;193: 195-205.

53. Kanazawa S, Fujiwara T, Matsuzaki S, et al. bFGF regulates PI3-kinase-Rac1-JNK pathway and promotes fibroblast migration in wound healing. PLoS One. 2010;5(8):e12228.

54. Mitsui Y, Imamura T. Growth regulation of vascular cells by FGFs and a novel ECGF. Tanpakushitsu Kakusan Koso. 1991;36(7):1237-46 (In Japanese).

55. Satoh T, Kan M, Masuko K, Obinata M. Characterization of a new endothelial cell growth factor (fECGF) partially purified from the supernatant of human fibroblast cells. Cell Struct Funct. 1989;14(6):731-40.

56. Wiecha J, Munz B, Wu Y, Noll T, Tillmanns H, Waldecker B. Blockade of $\mathrm{Ca}^{2+}$-activated $\mathrm{K}^{+}$channels inhibits proliferation of human endothelial cells induced by basic fibroblast growth factor. J Vasc Res. 1998;35:363-71.

57. Seghezzi G, Patel S, Ren CJ, et al. Fibroblast growth factor-2 (FGF-2) induces vascular endothelial growth factor (VEGF) expression in the endothelial cells of forming capillaries: an autocrine mechanism contributing to angiogenesis. J Cell Biol. 1998;141(7):1659-73.

58. Gospodarowicz D, Plouet J, Malerstein B. Comparison of the ability of basic and acidic fibroblast growth factor to stimulate the proliferation of an established keratinocyte cell line: modulation of their biological effects by heparin, transforming growth factor beta (TGF beta), and epidermal growth factor (EGF). J Cell Physiol. 1990;142: 325-33.

59. Halaban R, Langdon R, Birchall N, et al. Basic fibroblast growth factor from human keratinocytes is a natural mitogen for melanocytes. J Cell Biol. 1988;107(4):1611-9.

60. Xu H-L, Tian F-R, Xiao J, et al. Sustained-release of FGF-2 from a hybrid hydrogel of heparin-poloxamer and decellular matrix promotes the neuroprotective effects of proteins after spinal injury. Int J Nanomed. 2018;13:681-94.

61. Davis MG, Zhou M, Ali S, Coffin JD, Doetschman T, Dorn GW 2nd. Intracrine and autocrine effects of basic fibroblast growth factor in vascular smooth muscle cells. J Mol Cell Cardiol. 1997;29(4): 1061-72.

62. Sugamata A, Yoshizawa N, Oyama S. Treatment of fingertip amputation using a combination of artificial dermis and bFGF formulation. Prog Med. 2006;26:2731-5.

63. Edelman ER, Nugent MA, Karnovsky MJ. Perivascular and intravenous administration of basic fibroblast growth factor: vascular and solid organ deposition. Proc Natl Acad Sci USA. 1993;90: 1513-7.

64. Xiang Q, Xiao J, Zhang HB, et al. Preparation and characterisation of bFGF-encapsulated liposomes and evaluation of wound healing activities in the rat. Burns. 2011;37:886-95.

65. Kawai K, Suzuki S, Tabata Y, et al. Accelerated tissue regeneration through incorporation of basic fibroblast growth factor-impregnated gelatin microspheres into artificial dermis. Biomaterials. 2000;21(5):489-99.

66. Kanda N, Morimoto N, Takemoto S, et al. Efficacy of novel collagen/gelatin scaffold with sustained release of basic fibroblast growth factor for dermislike tissue regeneration. Ann Plast Surg. 2012;69(5): 569.

67. Kanda N, Morimoto N, Ayvazyan AA, et al. Evaluation of a novel collagen-gelatin scaffold for achieving the sustained release of basic fibroblast growth factor in a diabetic mouse model. J Tissue Eng Regen Med. 2014;8(1):29-40.

68. Tabata Y, Ikada Y. Vascularization effect of basic fibroblast growth factor released from gelatin hydrogels with different biodegradabilities. Biomaterials. 1999;20:2169-75.

69. Tabata Y, Nagano A, Ikada Y. Biodegradation of hydrogel carrier incorporating fibroblast growth factor. Tissue Eng. 1999;5:127-38.

70. Mizuno K, Yamamura K, Yano K, et al. Effect of chitosan film containing basic fibroblast growth factor on wound healing in genetically diabetic mice. J Biomed Mater Res A. 2003;64(1):177-81.

71. Richard JL, Parer-Richard C, Daures JP, et al. Effect of topical basic fibroblast growth factor on the healing of chronic diabetic neuropathic ulcer of the foot. A pilot, randomized, double-blind, placebocontrolled study. Diabetes Care. 1995;18(1):64-9.

72. Matsumoto S, Tanaka R, Okada K, et al. The effect of control-released basic fibroblast growth factor in wound healing: histological analyses and clinical 
application. Plast Reconstr Surg Glob Open. 2013;1(6):e44.

73. Steed DL. Clinical evaluation of recombinant human platelet-derived growth factor for the treatment of lower extremity ulcers. Plast Reconstr Surg. 2006;117(7 Suppl):143S-51S.

74. Papanas N, Maltezos E. Benefit-risk assessment of becaplermin in the treatment of diabetic foot ulcers. Drug Saf. 2010;33:455-61.

75. Rees RS, Robson MC, Smiell JM, Perry BH. Becaplermin gel in the treatment of pressure ulcers: a phase II randomized, double-blind, placebo-controlled study. Wound Repair Regen. 1999;7:141-7.

76. Senger DR, Ledbetter SR, Claffey KP, PapadopoulosSergiou A, Peruzzi CA, Detmar M. Stimulation of endothelial cell migration by vascular permeability factor/vascular endothelial growth factor through cooperative mechanisms involving the alphavbeta3 integrin, osteopontin, and thrombin. Am J Pathol. 1996;149:293-305.

77. Galiano RD, Tepper OM, Pelo CR, et al. Topical vascular endothelial growth factor accelerates diabetic wound healing through increased angiogenesis and by mobilizing and recruiting bone marrowderived cells. Am J Pathol. 2004;164:1935-47.

78. Mineur P, Colige AC, Deroanne CF, et al. Newly identified biologically active and proteolysis-resistant VEGF-A isoform VEGF111 is induced by genotoxic agents. J Cell Biol. 2007;179:1261-73.

79. Chen HX, Cleck JN. Adverse effects of anticancer agents that target the VEGF pathway. Nat Rev Clin Oncol. 2009;6:46577.

80. Gainza G, Villullas S, Pedraz JL, Hernandez RM, Igartua $M$. Advances in drug delivery systems (DDSs) to release growth factors for wound healing and skin regeneration. Nanomedicine. 2015;11: 1551-73.
81. Tiaka EK, Papanas N, Manolakis AC, Georgiadis GS. Epidermal growth factor in the treatment of diabetic foot ulcers: an update. Perspect Vasc Surg Endovasc Ther. 2012;24:37-44.

82. Saijo H, Hayashida K, Morooka S, Fujioka M. Combined treatment with artificial dermis and basic fibroblast growth factor for cranial bone-exposing wounds. J Tissue Viability. 2015;24(4): 173-9.

83. Kurokawa I, Hayami J, Kita Y. A therapy-resistant chronic leg ulcer treated successfully with topical basic fibroblast growth factor. J Int Med Res. 2003;31(2):149-51.

84. Asai J, Takenaka H, Ichihashi K, Ueda E, Katoh N, Kishimoto S. Successful treatment of diabetic gangrene with topical application of a mixture of peripheral blood mononuclear cells and basic fibroblast growth factor. J Dermatol. 2006;33(5): 349-52.

85. Ito $\mathrm{K}$, Ito $\mathrm{S}$, Sekine $\mathrm{M}$, Hori $\mathrm{K}$, Wada T. Reconstruction of the soft tissue of the heel with artificial dermis and recombinant basic fibroblast growth factor: case report. Foot Ankle Int. 2006;27(1):56-9.

86. Akita $\mathrm{S}$, Akino $\mathrm{K}$, Imaizumi $\mathrm{T}$, Hirano A. A basic fibroblast growth factor improved the quality of skin grafting in burn patients. Burns. 2005;31(7): 855-8.

87. Muneuchi G, Suzuki S, Moriue T, Igawa HH. Combined treatment using artificial dermis and basic fibroblast growth factor (bFGF) for intractable fingertip ulcers caused by atypical burn injuries. Burns. 2005;31(4):514-7.

88. Yamanaka $\mathrm{K}$, Inaba $\mathrm{T}$, Nomura $\mathrm{E}$, et al. Basic fibroblast growth factor treatment for skin ulcerations in scleroderma. Cutis. 2005;76(6):373-6. 